\title{
Precursors of Student Engagement in Indian Milieu
}

\section{Teena Singh, Sombala Ningthoujam}

New Delhi Institute of Management, New Delhi, India

Email: teena.singh@ndimdelhi.org

How to cite this paper: Singh, T. and Ningthoujam, S. (2020) Precursors of Student Engagement in Indian Milieu. Theoretical Economics Letters, 10, 102-118. https://doi.org/10.4236/tel.2020.101007

Received: September 18, 2019

Accepted: January 28, 2020

Published: February 4, 2020

Copyright $\odot 2020$ by author(s) and Scientific Research Publishing Inc. This work is licensed under the Creative Commons Attribution International License (CC BY 4.0).

http://creativecommons.org/licenses/by/4.0/

\begin{abstract}
The topic of student engagement has captured much research attention lately. However, there still remains a paucity of empirical work on the construct in Indian context. Therefore, the current investigation seeks to identify the precursors or antecedents of student engagement in Indian institutes. Sample of the current study comprised of 717 respondents from University students. Results indicate that Student engagement is a function of certain situational factors such as academic facilities, faculty, role of administration as well as some personality factors viz. locus of control and self-efficacy.
\end{abstract}

\section{Keywords}

Self-Efficacy, Locus of Control, Student Engagement, Situational Factors

\section{Introduction}

Student engagement is a widely studied topic in the United States because it has been found to be correlated with learning and personal development [1] [2] [3]. Interest in student engagement is increasingly widespread within educational circles [4]. Student engagement is said to lead to school dropout prevention [5].

Engaged students are good learners and effective teaching stimulates and sustains student engagement [2]. Studies have highlighted the importance of student engagement by revealing its influence on student performance. Many recent studies also established a positive relationship between student engagement and outcomes such as educational development of students [6] [7] [8]. [6], conducted a comprehensive literature review pertaining to education that underlined the beneficial learning outcomes of student engagement. Active participation of students in the learning process has shown to influence academic achievement.

Although, student engagement is a widely studied concept in USA, UK, Aus- 
tralia and Spain, very few studies in the area of student engagement were found in the Indian context [9] [10] [11] [12]. Therefore, it was decided to carry out the research study in the Indian context.

\section{The objectives of the study are:}

1) To explore the role of personal attribute as precursor of student engagement among the Indian millennial.

2) To explore the role of situational factor as precursor of student engagement among the Indian millennial.

\section{Review of Literature}

According to [13], student engagement may be understood in terms of the cognitive and affective systems of learners and readers. It is also conceptualized as a psychological process, specifically, the attention, interest, investment and effort students expend in the work of learning [14]. [15], defines student engagement in terms of the time and energy students invest in educationally purposeful activities. It is active involvement, commitment and sense of belonging that dictates the time and effort students devote to educationally purposeful activities [16].

Researchers in the fields of education and psychology have extensively studied interest, engagement and motivation [17] [18] [19]. According to [20], students' attitude and motivation towards, and interest in school science along with their beliefs as learners can positively influence the quality and quantity of learning outcomes, and are vital to their engagement in science learning [21]. Studies have highlighted the importance of student engagement by revealing its influence on student performance. [22], discovered a positive relationship between student engagement and variables such as satisfaction with college, educational aspirations, intellectual and personal development, academic achievement, and persistence in college. Active participation of students in the learning process has shown to influence academic achievement [11] [23]. Studies from showed a correlation between low behavioral engagement and cutting class, skipping school, suspension, and retention [24] [25]. [26], showed that students who eventually drop out do less homework, exert less effort in school, participate less in school activities, and have more discipline problems at school. Other studies of urban minority samples demonstrate a correlation between low behavioral engagement and cutting class, skipping school, suspension, and retention [24] [25]. There is scholarly research evidence to suggest that a positive correlation exists between behavioral engagement and achievement-related outcomes [14] [24] [27]. Other studies have reported association of discipline problems with lower school performance [28] [29].

Some dimensions measure behavioral and affective components in the form of student participation in school activities (inside and outside), identification with and sense of belongingness towards school while some others measure student engagement as a four dimensional construct. [30], proposed a model of context, 
student engagement and outcomes where student engagement had four dimensions: academic engagement elements that included time on task, credit hours for graduation and homework completion; behavioral dimensions comprising attendance, classroom participation (voluntary), extra-curricular participation and extra credit options; cognitive dimensions constituted of self-regulation, relevance of school to future aspirations, value of learning (goal setting) and strategizing; and psychological dimension representing sense of belonging and identification with school, and school membership.

There is a totally different school of thought which considers engagement an antipode of burnout [31], in their cross national study of university students from Spain, identified three dimensions, namely vigor- it describes the energy that one invests in the activity at hand; dedication - in terms of commitment and clarity towards work; and absorption - it refers to the state of involvement or immersion in the task or work at hand. Active and collaborative learning, academic, behavioral, cognitive, affective/emotional, student-faculty, supportive environment, participation, challenge, intellectual, online, beyond class, etc. are some of the dimensions which have been used to study student engagement [2] [15] [17] [32] [33] [34].

A longitudinal study on a sample of 11,827 French-Canadian high school students was conducted to see the engagement in terms of behavioral, affective, cognitive dimensions and result confirmed the overall multidimensional construct of school engagement in terms of both cognitive and psychosocial characteristics [35].

\section{Precursors of Student Engagement}

While student engagement is accepted as one of the superior predictors of learning, consensus on its conceptual foundation still remains elusive [36]. It has been generally accepted that there is a need to examine precursors and outcomes of student engagement. Several studies have empirically tried to explain how specific student characteristics (e.g., school-related self-efficacy, gender, academic motivation etc.), family environment (e.g., parent social support, aspirations of parents concerning the adolescents' school trajectory or quality of adolescent-parents relationship), and school/classroom climate (e.g., social support from teachers and peers, autonomy granted to students, quality of instructional practices etc.) influence student engagement with school and academic performance [37].

[38], stated that institutions can influence a range of behaviors such as student engagement with teaching practices and programming interventions such as first year seminars, service-learning outcomes and learning communities. On the other hand, voluntary choice, clear and consistent goals, small size, student participation in school policy and management, opportunities for staff and students to be involved in cooperative endeavors, and academic work that allows for the development of products were found to increase student involvement, engagement, and integration in school. Disciplinary practices and communal structures 
were found to encourage shared responsibility and commitment to common goals, lateral decision making, and greater individual discretion [39].

[40], compared student engagement between colleges and universities in the U.S. and Canada. Results suggest that students in Canada and the U.S. differed in terms of the frequency with which they engaged in active and collaborative learning and student-faculty interaction. It appears that the Canadian classroom experience involves less active participation by students and less individual contact with faculty members. The large size of most Canadian universities and higher student-faculty ratios makes collaborative learning experiences and faculty contact more challenging.

Several studies have empirically tried to explain how specific student characteristics (e.g., school-related self-efficacy, gender, academic motivation etc.), family environment (e.g., parent social support, aspirations of parents concerning the adolescents' school trajectory or quality of adolescent-parents relationship), and school/classroom climate (e.g., social support from teachers and peers, autonomy granted to students, quality of instructional practices etc.) influence student engagement with school and academic performance [37]. Student engagement has been studied by many authors as an outcome of certain factors. These factors can be categorized into individual/personal attributes, and contextual factors which may include institutional and relationship factors and their impact on student engagement. [36], engagement is not a one-dimensional construct; students could be emotionally, physically, and cognitively be engaged in class, or cognitively engaged out of class. Understanding the aforementioned four factors could help academics engage students [36].

\section{Personal Attributes as precursor of Student Engagement}

[41], showed that intrinsic motivation, self-efficacy and academic identification each contributed uniquely towards predicting meaningful cognitive engagement. Also, establishing achievement goals contributed towards prediction of school performance [42]. Mastery orientation seems linked with positive academic behaviors like asking for help [43], and absence of disruptive behaviors in the classroom [44] [45].

Study by [46], found Self-concept of ability to be a significant predictor of engagement among Australian high school students. Similarly [47], found that current efficacy beliefs influence high levels of academic engagement which, in turn, influences students' self-efficacy over time. Study conducted by [48], on a sample consisting of five hundred and seventy eight middle and high school students found that cognitive engagement predicts academic performance whereas emotional and behavioral engagement does not predict academic performance. Also the study highlighted the role of academic self-efficacy and academic motivation as predicting academic performance.

Study undertaken by [49], on a sample of 203 students enrolled in online study mode in USA found that Situational interest and self-regulation were significantly correlated with behavioural, emotional and cognitive engagement 
while computer self-efficacy was found to be not related to engagement. According to [50], instructors who used thematic coherence, teaching within a context along with teaching template using the 5Es (Engage, Explore, Explain, Elaborate and Evaluate) were found to be rewarded and rated highly to the instructor and courses by engaged and motivated students. [30], proposed a model with some context factors, namely family, peers and school related factors that influenced student engagement. The family context comprises of academic and motivational support in terms of expectation, goal achievement and supervision from home. Peer related factors comprised educational expectations, shared common school value, attendance and peers' aspiration for learning. School factors found to influence engagement were school climate, instructional programming and learning activities, mental health support, clear and appropriate teacher expectations, goal structure (task vs. ability) and teacher student relationships.

Another study of MBA students in an All-Women University identified six dimensions of student engagement, namely diligent pursuit of studies, commitment to the institution, emotional engagement, active academic participation, absorption of studies and interaction with faculty. Active academic participation was found to be rated very high in the sample whereas diligent pursuit of studies, emotional engagement and absorption were rated modest. Interaction with faculty both inside and outside the classroom and commitment to the institution were reported to be rated very low. A combination of two personality variables (LOC and self-efficacy), and academic inputs as the situational variable emerged as the best predictors for several dimensions of engagement [11]. [51] found that perceived emotional intelligence, self-efficacy and perceived stress were significant predictors of engagement. Many studies demonstrate a link between behavioral engagement and achievement [14] [24] [27]. So student engagement is crucial to learning, academic performance and is influenced by the presence and interaction of several factors like situational factors, and other personal attributes and background.

\section{Hypotheses:}

1) There exists positive significant relationship between personality attributes and Student engagement.

2) There exists positive significant relationship between situational factor and Student engagement.

\section{Research Method}

The total sample for the analysis is 717 respondents.

Table 1 explained descriptive profile of the sample, out of the 717 respondents, $59.3 \%$ of the respondents were male students followed by $40.7 \%$ of female students $43 \%$ were from Metro background, followed by 39.5\% respondents from city background, $15 \%$ from Town and $2.5 \%$ from village. $57.3 \%$ respondents were from Middle class socio economic family background, followed by 35.3\% Upper Middle Class. 
Table 1. Sample profiling.

\begin{tabular}{ccc}
\hline Demographic variables & N (717) & Percentage \\
Male & Gender & $59.3 \%$ \\
Female & 295 & $40.7 \%$ \\
& 292 & \\
Village & Student Domicile & $2.5 \%$ \\
Town & 18 & $15 \%$ \\
City & 108 & 39.5 \\
Metro & 283 & $43 \%$ \\
& 308 & $.6 \%$ \\
Lower Class(LC) & 4 & $4.6 \%$ \\
Lower Middle Class(LMC) & 33 & $57.3 \%$ \\
Middle Class (MC) & 411 & $35.3 \%$ \\
Upper Middle Class(UMC) & 253 & $2.2 \%$ \\
Upper Class (UC) & 16 &
\end{tabular}

\section{Research Design:}

This study intended to measure the engagement levels and its precursors among the Indian Millennials students. Since the present research work is based on primary data which was collected from post graduate management students studying in University Management Department, University affiliated institute and AICTE approved autonomous management institute based in Delhi with the help of structured questionnaire, a field based survey design is used as data collection method (Figure 1).

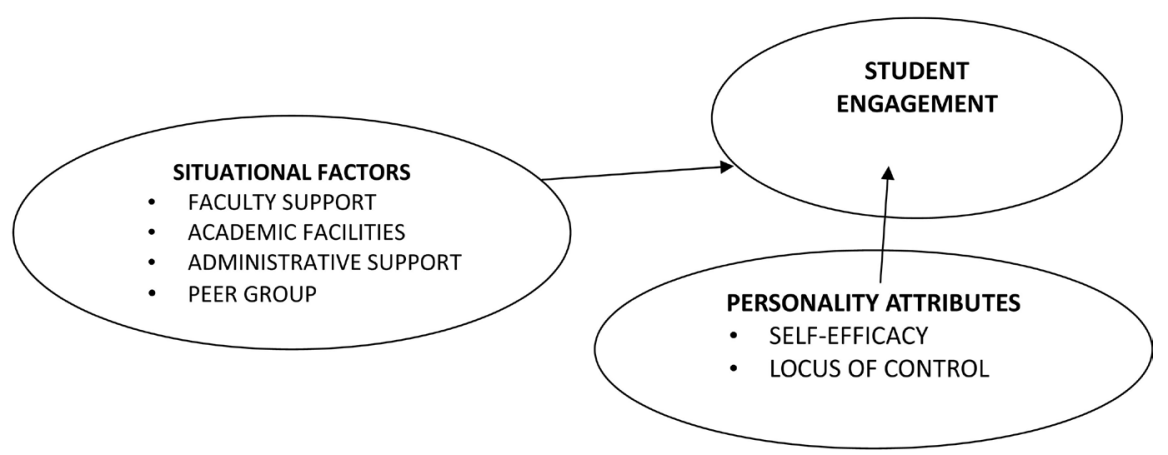

Figure 1. Study model.

\section{Tools:}

\section{Student engagement (17 items)}

1) Institutional Engagement 5 items

2) Diligence 3 items

3) Absorption 3 items

4) Dedication 4 items 


\section{5) Class Participation 3 items}

\section{Precursors:}

1) Personal factors: Self Efficacy (10 items) and Locus of control 10 items

2) Situational factors: 20 items

Table 2 depicts about the items used in the present study from existing scales and also added new items to assess the level of student engagement in higher education institutions in Indian context. The scale comprised of 17 items student engagement and precursors 40 items. Total of 57 items were used for the study.

Table 2. Variables and their items measurement.

\begin{tabular}{|c|c|c|}
\hline Factor No. & Factor & Items \\
\hline 1 & $\begin{array}{l}\text { Institutional Engagement } \\
\qquad(5 \text { items })\end{array}$ & $\begin{array}{l}\text { 1) If a friend of mine is considering joining this institute, I will encourage him/her to do so. } \\
\text { 2) The goals and values of this institute are in harmony with my own goals and values. } \\
\text { 3) I feel a sense of pride when I introduce myself to a stranger as a student of this institute. } \\
\text { 4) Based on my experience as a student here, I feel that my decision to join this institute was correct. } \\
\text { 5) In my overall assessment, this is one of the best business schools in India. }\end{array}$ \\
\hline 2 & Diligence (3 items) & $\begin{array}{l}\text { 1) It is my habit to take notes during the class. } \\
\text { 2) I make sure that my class assignments are completed before the deadline. } \\
\text { 3) I keep my course materials well organized. }\end{array}$ \\
\hline 3 & Absorption & $\begin{array}{l}\text { 1) I find it difficult to detach myself from my studies. } \\
\text { 2) Most of the time I am immersed in my studies. } \\
\text { 3) I feel excited when I am absorbed in my studies }\end{array}$ \\
\hline 5 & $\begin{array}{c}\text { Class } \\
\text { Participation (3 items) }\end{array}$ & $\begin{array}{l}\text { 1) I often ask questions in the class. } \\
\text { 2) I enjoy making presentations in the class. } \\
\text { 3) I actively participate in class discussions. }\end{array}$ \\
\hline \multicolumn{3}{|r|}{ Cronbach's alpha: overall reliability of the scale $=0.842$} \\
\hline $\mathrm{B}$ & $\begin{array}{l}\text { Personal factors (Self-efficacy } \\
\quad \text { \& Locus of Control) }\end{array}$ & $\begin{array}{l}\text { 1) Self-Efficacy Scale-[52], Schwarzer and Jerusalem (1995)-10 items } \\
\text { 2) Locus of Control-[53] Rotter Scale (1971) - } 10 \text { items }\end{array}$ \\
\hline Precursors & Situational factors, [15] & $\begin{array}{l}\text { 1) Faculty Support; 2) Academic Facilities; 3) Administrative Staff Support; 4) Peer Group (5 items } \\
\text { each making a total of } 20 \text { items) }\end{array}$ \\
\hline
\end{tabular}

\section{Results and Discussion}

Table 3 presents descriptive statistics for all variables under study. Out of the five dimensions of student engagement, students are showing high level of diligence in student engagement with the highest mean score of 2.05. The students are found to be moderately engaged in terms of Dedication, Class participation and Institutional engagement dimensions of student engagement with mean scores of 1.96, 1.93 and 1.80 respectively. Students are found to be least engaged to Absorption dimension of student engagement with a mean score of 1.61. Overall, the level of student engagement was found to be moderate. In terms of personal factors, the students have scored high Internal Locus of Control with 3.91 mean score and scored above average on self-efficacy with 1.91 mean score. In situational factors, the students appear to be more satisfied with Peer Group 
as the mean score comes out to be high at 2.14. Faculty support is perceived as above average with 1.86 mean score, followed by average mean score of Academic Facilities at 1.84 and low mean score of administrative staff support at 1.71. The Faculty support could be related to the helpful attitude of the faculty, faculty inputs or the pedagogical tools used in the classroom. To summarize the findings of descriptive statistics, Diligence out of 5 Student Engagement dimensions was found to have the highest Mean score of 2.05. Peer Group out of 4 Situational Factors had the highest mean of 2.14 and Locus of Control out of 2 Personal Factors had the highest mean of 3.91 .

Table 3. Descriptive statistics.

\begin{tabular}{cccc}
\hline S. No. & Variable & Mean & Standard Deviation \\
\hline \multicolumn{3}{c}{ Student Engagement } & \\
2 & Diligence & 2.05 & 0.58 \\
3 & Class Participation & 1.93 & 0.63 \\
4 & Dedication & 1.96 & 0.55 \\
5 & Institutional Engagement & 1.80 & 0.60 \\
& Absorption & 1.61 & 0.62 \\
6 & Personality factors & & \\
7 & Self-Efficacy & 1.97 & 0.40 \\
8 & Locus of Control & 3.91 & 1.09 \\
9 & Situational factors & & 0.45 \\
10 & Peer Group & 2.14 & 0.53 \\
11 & Faculty Support & 1.86 & 0.52 \\
\hline
\end{tabular}

Table 4 depicts correlation among the variables. Both of the two personal factors-self-efficacy and locus of Control are positively and significantly correlated with each of the five dimensions of student engagement. The association between three out of four dimensions of situational factors and student engagement is also showing positively and significantly correlated with each of the five dimensions of student engagements except in case of Peer Group Relations which is showing positive and significant correlations for 4 out of 5 dimensions of student engagement except for Institutional Engagement Dimension which is not found significant.

\section{Regression Analysis}

There are 5 dimensions of student engagement in the study and Multiple Regression Analysis has been done to see how independent variables which are 6 i.e. Situational Factors namely (Academic facilities, Faculty Support, Administrative staff Support and Peer group) and Personal factors namely (Self efficacy 
Table 4. Correlation matrix for the selected variables $(\mathrm{N}=717)$.

\begin{tabular}{|c|c|c|c|c|c|c|c|c|c|c|c|}
\hline & 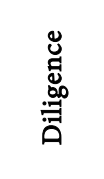 & 兽 & 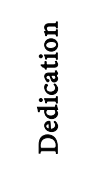 & $\begin{array}{l}\text { 品 } \\
\text { 品 } \\
\dot{\overrightarrow{0}} \\
\vdots\end{array}$ & 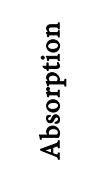 & 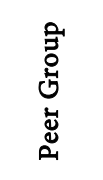 & 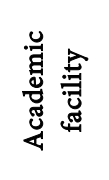 & 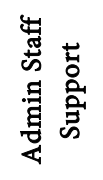 & 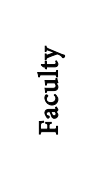 & 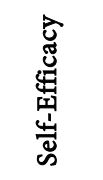 & ర్త \\
\hline Diligence & 1 & & & & & & & & & & \\
\hline Class Participation & $0.465^{\star *}$ & 1 & & & & & & & & & \\
\hline Dedication & $0.447^{* *}$ & $0.426^{\star *}$ & 1 & & & & & & & & \\
\hline Institutional. Engagement & $0.432^{\star *}$ & $0.431^{\star *}$ & $0.457^{\star \star}$ & 1 & & & & & & & \\
\hline Absorption & $0.496^{\star *}$ & $0.447^{\star *}$ & $0.436^{\star *}$ & $0.407^{\star *}$ & 1 & & & & & & \\
\hline Peer Group & $0.560^{\star *}$ & $0.556^{\star *}$ & $0.587^{\star}$ & 0.417 & $0.505^{\star *}$ & 1 & & & & & \\
\hline Academic facility & $0.577^{\star *}$ & $0.545^{\star *}$ & $0.538^{* *}$ & $0.404^{\star *}$ & $0.502^{* *}$ & $0.444^{* *}$ & 1 & & & & \\
\hline Admin Staff Support & $0.536^{\star *}$ & $0.552^{\star *}$ & $0.582^{* *}$ & $0.511^{\star *}$ & $0.564^{\star *}$ & $0.422^{* *}$ & $0.407^{* *}$ & 1 & & & \\
\hline Faculty & $0.526^{\star *}$ & $0.517^{\star *}$ & $0.590^{\star *}$ & $0.556^{\star *}$ & $0.555^{\star *}$ & $0.420^{\star *}$ & $0.416^{\star *}$ & $0.410^{\star *}$ & 1 & & \\
\hline Self-efficacy & $0.584^{\star *}$ & $0.587^{\star *}$ & $0.558^{* *}$ & $0.579^{\star *}$ & $0.581^{\star *}$ & $0.412^{\star *}$ & $0.451^{\star *}$ & $0.430^{\star *}$ & $0.425^{\star *}$ & 1 & \\
\hline LOC & $0.551^{\star *}$ & $0.599^{* *}$ & $0.514^{* *}$ & 0.526 & 0.534 & $0.418^{* *}$ & 0.423 & 0.441 & $0.413^{* *}$ & $0.430^{* *}$ & 1 \\
\hline
\end{tabular}

${ }^{* *}$ Correlation is significant at the 0.01 level (2-tailed). ${ }^{*}$ Correlation is significant at the 0.05 level (2-tailed).

and Locus of control) have impact on the dependent variables. Since there are 5 dependent variables i.e. 5 dimensions of Student Engagement accordingly 5 multiple regression analysis have been done.

\section{$1^{\text {st }}$ Dimension of Student Engagement-Diligence}

Results of Multiple Regression Analysis on Diligence Dimension of Student Engagement and 6 Independent variables are reported below (Table 5).

It was found that Self Efficacy, Faculty Support, Peer Group and Administrative Staff Support were not found to be significant. The results revealed that $11.3 \%$ variance in Diligence is explained by the predictors as Independent Variables. Out of 6 independent variables only 2 were found to be having the influence and were Academic Facilities and Locus of Control.

\section{$2^{\text {nd }}$ Dimension of Student Engagement-Class Participation (Table 6)}

The results revealed that $6.5 \%$ variation in Class Participation is explained by the predictors i.e. Faculty Support and Self-Efficacy as Independent Variables. Although the value is less but still influence of these predictors on Class Participation is explained. Out of 6 independent variables only 2 were found to be having the influence and were Faculty Support and Self-Efficacy.

\section{$3^{\text {rd }}$ Dimension of Student Engagement-Dedication (Table 7)}

The above results revealed that $9.9 \%$ variation in Dedication is explained by the predictors as independent variables. Out of 6 independent variables only 2 were found to be having the influence and were Academic Facilities and Self-Efficacy. It was found that Locus of Control, Faculty Support, Administrative Staff Support and Peer Group were not found to be significant.

\section{$4^{\text {th }}$ Dimension of Student Engagement-Institutional Engagement (Table 8)}


Table 5. (a) Regression coefficients of diligence dimension; (b) Diligence dimension regression model summary.

(a)

\begin{tabular}{|c|c|c|c|c|c|c|}
\hline & \multirow[t]{2}{*}{ Model } & \multicolumn{2}{|c|}{$\begin{array}{l}\text { Unstandardized } \\
\text { Coefficients }\end{array}$} & \multirow{2}{*}{$\begin{array}{c}\begin{array}{c}\text { Standardized } \\
\text { Coefficients }\end{array} \\
\text { Beta }\end{array}$} & \multirow[t]{2}{*}{$\mathrm{T}$} & \multirow[t]{2}{*}{ Sig. } \\
\hline & & B & Std. Error & & & \\
\hline \multirow{7}{*}{1} & (Constant) & 0.872 & 0.138 & & 6.310 & 0.000 \\
\hline & LOC & 0.053 & 0.019 & 0.100 & 2.743 & 0.006 \\
\hline & Peer Group & 0.092 & 0.050 & 0.071 & 1.823 & 0.069 \\
\hline & Academic Facilities & 0.178 & 0.048 & 0.164 & 3.721 & 0.000 \\
\hline & Administrative Staff Support & 0.088 & 0.047 & 0.084 & 1.883 & 0.060 \\
\hline & Faculty Support & 0.082 & 0.051 & 0.076 & 1.601 & 0.110 \\
\hline & Self-Efficacy & 0.078 & 0.060 & 0.052 & 1.289 & 0.198 \\
\hline
\end{tabular}

a. Dependent Variable: diligence.

(b)

\begin{tabular}{cccccc}
\hline Model & R & R Square & Adjusted R Square & $\begin{array}{c}\text { Std. Error of the } \\
\text { Estimate }\end{array}$ & Durbin-Watson \\
\hline 1 & $0.348^{\mathrm{a}}$ & 0.121 & 0.113 & 0.54929 & 1.724 \\
\hline
\end{tabular}

a. Predictors: (Constant), self-efficacy, administrative support, loc, peer group, academic facilities, faculty support; b. Dependent Variable: diligence.

Table 6. (a) Regression coefficients of class participation dimension; (b) Regression model summary of class participation dimension.

(a)

\begin{tabular}{|c|c|c|c|c|c|c|}
\hline & \multirow[t]{2}{*}{ Model } & \multicolumn{2}{|c|}{$\begin{array}{l}\text { Unstandardized } \\
\text { Coefficients }\end{array}$} & \multirow{2}{*}{$\begin{array}{c}\begin{array}{c}\text { Standardized } \\
\text { Coefficients }\end{array} \\
\text { Beta }\end{array}$} & \multirow[t]{2}{*}{$\mathrm{t}$} & \multirow[t]{2}{*}{ Sig. } \\
\hline & & B & Std. Error & & & \\
\hline \multirow{7}{*}{1} & (Constant) & 0.914 & 0.153 & & 5.979 & 0.000 \\
\hline & LOC & 0.024 & 0.021 & 0.041 & 1.105 & 0.269 \\
\hline & Peer Group & 0.102 & 0.056 & 0.073 & 1.832 & 0.067 \\
\hline & Academic Facilities & 0.012 & 0.053 & 0.010 & 0.220 & 0.826 \\
\hline & dministrative Staff Support & 0.033 & 0.052 & 0.029 & 0.640 & 0.523 \\
\hline & Faculty Support & 0.180 & 0.057 & 0.153 & 3.164 & 0.002 \\
\hline & Self-Efficacy & 0.149 & 0.067 & 0.093 & 2.234 & 0.026 \\
\hline
\end{tabular}

a. Dependent Variable: Class Participation.

(b)

\begin{tabular}{cccccc}
\hline Model & R & R Square & Adjusted R Square & $\begin{array}{c}\text { Std. Error of the } \\
\text { Estimate }\end{array}$ & Durbin-Watson \\
\hline 1 & $0.271^{\mathrm{a}}$ & 0.073 & 0.065 & 0.60769 & 1.659 \\
\hline
\end{tabular}

a. Predictors: (Constant), Self-efficacy, Admin. support, Loc, Peer-group, Acad. facilities, Faculty support;

b. Dependent Variable: Class Participation. 
Table 7. (a) Regression coefficients of dedication dimension; (b) Dedication dimension regression model summary.

(a)

\begin{tabular}{|c|c|c|c|c|c|c|}
\hline & \multirow[t]{2}{*}{ Model } & \multicolumn{2}{|c|}{$\begin{array}{l}\text { Unstandardized } \\
\text { Coefficients }\end{array}$} & \multirow{2}{*}{$\begin{array}{c}\begin{array}{c}\text { Standardized } \\
\text { Coefficients }\end{array} \\
\text { Beta }\end{array}$} & \multirow[t]{2}{*}{$\mathrm{t}$} & \multirow[t]{2}{*}{ Sig. } \\
\hline & & B & Std. Error & & & \\
\hline \multirow{7}{*}{1} & (Constant) & 0.971 & 0.131 & & 7.389 & 0.000 \\
\hline & Locus of Control & 0.028 & 0.018 & 0.057 & 1.542 & 0.123 \\
\hline & Peer group & -0.052 & 0.048 & -0.043 & -1.088 & 0.277 \\
\hline & Academic Facilities & 0.148 & 0.045 & 0.145 & 3.257 & 0.001 \\
\hline & Administrative Staff Support & 0.051 & 0.045 & 0.052 & 1.143 & 0.253 \\
\hline & Faculty Support & 0.035 & 0.049 & 0.034 & 0.710 & 0.478 \\
\hline & Self-efficacy & 0.290 & 0.057 & 0.207 & 5.056 & 0.000 \\
\hline
\end{tabular}

a. Dependent Variable: Dedication.

(b)

\begin{tabular}{cccccc}
\hline Model & R & R Square & $\begin{array}{c}\text { Adjusted R } \\
\text { Square }\end{array}$ & $\begin{array}{c}\text { Std. Error of the } \\
\text { Estimate }\end{array}$ & Durbin-Watson \\
\hline 1 & $0.327^{\mathrm{a}}$ & 0.107 & 0.099 & 0.52247 & 1.669 \\
\hline
\end{tabular}

a. Predictors: (Constant), self-efficacy, administrative support, locus of control, peer group, academic facilities, faculty support; b. Dependent Variable: Dedication.

Table 8. (a) Regression coefficients of institutional engagement dimension; (b) Institutional engagement dimension regression model summary.

(a)

\begin{tabular}{|c|c|c|c|c|c|c|}
\hline & \multirow[t]{2}{*}{ Model } & \multicolumn{2}{|c|}{$\begin{array}{l}\text { Unstandardized } \\
\text { Coefficients }\end{array}$} & \multirow{2}{*}{$\begin{array}{c}\begin{array}{c}\text { Standardized } \\
\text { Coefficients }\end{array} \\
\text { Beta }\end{array}$} & \multirow[t]{2}{*}{$\mathrm{T}$} & \multirow[t]{2}{*}{ Sig. } \\
\hline & & B & Std. Error & & & \\
\hline \multirow{7}{*}{1} & (Constant) & 0.686 & 0.132 & & 5.181 & 0.000 \\
\hline & LOC & 0.004 & 0.019 & 0.008 & 0.226 & 0.822 \\
\hline & Peer Group & -0.139 & 0.048 & -0.105 & -2.882 & 0.004 \\
\hline & Academic Facilities & 0.241 & 0.046 & 0.216 & 5.277 & 0.000 \\
\hline & Administrative Support & 0.219 & 0.045 & 0.203 & 4.875 & 0.000 \\
\hline & Faculty Support & 0.160 & 0.049 & 0.143 & 3.255 & 0.001 \\
\hline & Self-Efficacy & 0.129 & 0.058 & 0.084 & 2.230 & 0.026 \\
\hline
\end{tabular}

a. Dependent Variable: Institutional engagement.

(b)

\begin{tabular}{cccccc}
\hline Model & R & R Square & Adjusted R Square & $\begin{array}{c}\text { Std. Error of the } \\
\text { Estimate }\end{array}$ & Durbin-Watson \\
\hline 1 & $0.487^{\mathrm{a}}$ & 0.237 & 0.231 & 0.52620 & 1.655 \\
\hline
\end{tabular}

a. Predictors: (Constant), self-efficacy, administrative support, locus of control, peer group, academic facilities, faculty support; b. Dependent Variable: Institutional engagement. 
The results revealed that $23.1 \%$ variance in Institutional Engagement is explained by the predictors as Independent Variables. Out of 6 Independent Variables only 2 were found to be having the highest influence and were Academic Facilities and Administrative Staff Support.

\section{$5^{\text {th }}$ Dimension of Student Engagement-Absorption (Table 9)}

The results revealed that $5.6 \%$ variation in Absorption is explained by the predictors as independent variables. Out of 6 independent variables only 2 were found to be having the influence and were Academic Facilities and Self-Efficacy. It was found that faculty support, administrative staff support, Peer Group and Locus of control were not found to be significant.

Table 9. (a) Regression coefficients of absorption dimension; (b) Absorption dimension regression model summary.

(a)

\begin{tabular}{|c|c|c|c|c|c|c|}
\hline & \multirow[t]{2}{*}{ Model } & \multicolumn{2}{|c|}{$\begin{array}{l}\text { Unstandardized } \\
\text { Coefficients }\end{array}$} & \multirow{2}{*}{$\begin{array}{c}\begin{array}{c}\text { Standardized } \\
\text { Coefficients }\end{array} \\
\text { Beta }\end{array}$} & \multirow[t]{2}{*}{$t$} & \multirow[t]{2}{*}{ Sig. } \\
\hline & & B & Std. Error & & & \\
\hline \multirow{7}{*}{1} & (Constant) & 0.746 & 0.153 & & 4.863 & 0.000 \\
\hline & LOC & -0.009 & 0.022 & -0.015 & -0.395 & 0.693 \\
\hline & Peer Group & 0.036 & 0.056 & 0.026 & 0.646 & 0.519 \\
\hline & Academic Facilities & 0.139 & 0.053 & 0.119 & 2.616 & 0.009 \\
\hline & Administrative Staff Support & 0.064 & 0.052 & 0.057 & 1.234 & 0.218 \\
\hline & Faculty Support & 0.044 & 0.057 & 0.038 & 0.772 & 0.441 \\
\hline & Self-Efficacy & 0.194 & 0.067 & 0.121 & 2.899 & 0.004 \\
\hline
\end{tabular}

a. Dependent Variable: absorption.

(b)

\begin{tabular}{cccccc}
\hline Model & R & R Square & Adjusted R Square & $\begin{array}{c}\text { Std. Error of the } \\
\text { Estimate }\end{array}$ & Durbin-Watson \\
\hline 1 & $0.253^{\mathrm{a}}$ & 0.064 & 0.056 & 0.60995 & 1.560 \\
\hline
\end{tabular}

a. Predictors: (Constant), self-efficacy, administrative support, loc, peer group, academic facilities, faculty support; b. Dependent Variable: Absorption.

\section{Conclusion}

The students are found to be moderately engaged in terms of Diligence, Dedication, Class participation and Institutional engagement with mean scores of 2.05, $1.96,1.93$ and 1.80 respectively.

\section{Predictors of Student Engagement}

In terms of Personal Factors, the students are found to have scored moderate on Internal Locus of Control with a mean score of 3.91 and self-efficacy. In case of situational factors, the students appear to be more satisfied with Peer Group Relations as the mean score comes out to be very high at 2.14. Faculty support is 
perceived as above average with a mean score of 1.86 followed by average mean scores of 1.84 for Academic Facilities and 1.71 for Administrative Staff Support. Peer Group relations have emerged to play a major role in level of student engagement. It could be because of the perceived support one receives from a peer which motivates one to perform better. The Faculty support could be related to the helpful attitude of the faculty, faculty inputs or the pedagogical tools used in the classroom.

In search for the predictors of student engagement using multiple regression, mixed results were found. Self-efficacy has emerged as a strong predictor for 4 out of 5 dimensions of student engagement, namely Dedication, Absorption, Class Participation and Institutional Engagement and Locus of Control has emerged as a predictor for Diligence only. This finding is in consistence with earlier study of [41] showed that intrinsic motivation, self-efficacy and academic identification each contributed uniquely towards predicting meaningful cognitive engagement. Study of [51] also found that perceived emotional intelligence, self-efficacy and perceived stress were significant predictors of engagement. In terms of situational factors, Academic Facilities has emerged as a predictor of Dedication, Absorption, Diligence and Institutional Engagement except for Class Participation. This result is in consistence with the earlier study of [10] which identified predictors of student engagement and found that academic inputs and helpful administration were highly rated, followed by syllabus of the course and computer facilities. Faculty Support emerged as a predictor for Class Participation. Both Administrative Staff Support and Peer Group emerged as significant predictors of Institutional Engagement.

The study found out that situational factors and personal factors are important predictors of Student engagement. The Management institute should invest in improving the situational factors at the institution to improve the level of student engagement by providing training for dealing with students empathetically from diverse background so that the student grievance and query handling is improved. Academic Facilities like Library collections, IT infrastructure and IT enabled classroom environment must be incorporated in order to facilitate learning of students hence leading to better student engagement towards studies. Faculty members can provide more support as they have the major influence on the level of student engagement. This is in consistence with the previous studies on student engagement. Academic facilities and Administrative support have also emerged as predictors of student engagement. Improvement of Academic facilities and humane approach by administration will play a major role in improving the level of student engagement. More activities involving peer group may be used by faculty to increase class participation dimension of student engagement as it has been found to be the most important predictor of student engagement.

\section{Conflicts of Interest}

The author declares no conflicts of interest regarding the publication of this paper. 


\section{References}

[1] Astin, A.W. (1993) What Matters in College? Four Critical Years Revisited. The Journal of Higher Education, 22, 74-75. https://doi.org/10.2307/1176821

[2] Handelsman, M.M., Briggs, W.L., Sullivan, N. and Tower, A. (2005) A Measure of College Student Course Engagement. The Journal of Educational Research, 98, 184-191. https://doi.org/10.3200/JOER.98.3.184-192

[3] Floyd, K.S., Harrington, S.J. and Santiago, J. (2009) The Effect of Engagement and Perceived Course Value on Deep and Surface Learning Strategies. Informing Science: The International Journal of an Emerging Transdiscipline, 12, 80-190. https://doi.org/10.28945/3354 https://www.informingscience.org/Publications/435?Source=\%2FJournals\%2FInfor mingSciJ\%2FArticles\%3FVolume\%3D0-0

[4] Zyngier, D. (2005) Doing Education Not Doing Time. Engaging Pedagogies and Pedagogues-What Does Student Engagement Look like in Action? AARE 2004 Melbourne. Doing the Public Good: Positioning Education Research, Melbourne, 29 November-2 December 2004, 2-16.

https://www.semanticscholar.org/paper/Doing-education-not-doing-time.-Engagin g-pedagogies-Zyngier/2bdeed92ad76302d4275fcfe4a55a15fbf6d6028

[5] Alexander, K., Entwistle, D. and Horsey, C.S. (1997) From First Grade Forward: Early Foundations of High School Dropouts. Sociology of Education, 70, 87-107. https://doi.org/10.2307/2673158 https://eric.ed.gov/?id=EJ551245

[6] Kuh, G.D. and Umbach, P.D. (2004) College and Character: Insights from the National Survey of Student Engagement. New Directions for Institutional Research, 122, 37-54. https://doi.org/10.1002/ir.108

http://cpr.indiana.edu/uploads/Kuh,\%20Umbach\%20(2004)\%20College\%20and\%20 Character.pdf

[7] Pike, G.R. and Kuh, G.D. (2005) A Typology of Student Engagement for American Colleges and Universities. Research in Higher Education, 46, 185-209.

https://doi.org/10.1007/s11162-004-1599-0

[8] Strauss, L.C. and Terenzini, P.T. (2007) The Effects of Students In- and Out-of-Class Experiences on Their Analytical and Group Skills: A Study of Engineering Education. Research in Higher Education, 48, 967-992.

https://doi.org/10.1007/s11162-007-9057-4

http://www.jstor.org/stable/25704537

[9] Sharma, B., Khandelwal, S. and Ninghoujam, S. (2012) The Level of Student Engagement and Search for Its Predictors: An Exploratory Study of MBA Student. Metamorphosis, 11, 66-81. https://doi.org/10.1177/0972622520120206

[10] Sharma, B.R. and Bhaumik, P.K. (2013) Student Engagement and Its Predictors: An Exploratory Study in an Indian Business School. Global Business Review, 14, 25-42. https://doi.org/10.1177/0972150912466364

[11] Sharma, B.R., Jain, S. and Mittal, G. (2014) Determinants of Management Students' Engagement in a Women's University. Review of Management, 4, 31. http://www.mdrf.org.in/wp-content/uploads/2016/04/Review-of-Management-Vol. -4-No.-1-2-June-2014.pdf

[12] Singh, A.K. and Srivastava, S. (2014) Development and Validation of Student Engagement Scale in the Indian Context. Global Business Review, 15, 505-515. https://doi.org/10.1177/0972150914535137

[13] Guthrie, J.T., Wigfield, A., Barbosa, P., Perencevich, K.C., Tanoada, A., Davis, M.H., 
Scafiddi, N. and Tonks, S. (2004) Increasing Reading Comprehension and Engagement through Concept-Oriented Reading Instruction. Journal of Educational Psychology, 96, 403-423. https://doi.org/10.1037/0022-0663.96.3.403

[14] Marks, H.M. (2000) Student Engagement in Instructional Activity: Patterns in the Elementary, Middle, and High School Years. American Educational Research Journal, 37, 153-184. https://doi.org/10.3102/00028312037001153

[15] Kuh, G.D. (2001) Assessing What Really Matters to Student Learning: Inside the National Survey of Student Engagement. Change, 33, 10-17. https://doi.org/10.1080/00091380109601795

[16] Cleary, J. and Skaines, I. (2005) Student Engagement as a Quality Indicator at the University of Newcastle. AUQA Occasional Publications Number 5, Australian Universities Quality Forum, Sydney, 50-54.

[17] Fredricks, J.A., Blumenfeld, P.C. and Paris, A. (2004) School Engagement: Potential of the Concept: State of the Evidence. Review of Educational Research, 74, 59-119. https://doi.org/10.3102/00346543074001059

[18] Upadayaya, K. and Salmela-Aro, K. (2013) Development of School Engagement in Association with Academic Success and Well-Being in Varying Social Context. European Psychologist, 18, 136-147. https://doi.org/10.1027/1016-9040/a000143

[19] Eccles, J. and Wang, M.T. (2012) So, What Is Student Engagement Anyway? In: Christenson, S.L., Reschly, A.L. and Wylie, C., Eds., Handbook of Research on Student Engagement, Springer, New York, 133-145. https://doi.org/10.1007/978-1-4614-2018-7_6

[20] Osborne, J., Simon, S. and Collins, S. (2003) Attitude towards Science: A Review of the Literature and Its Implications. International Journal of Science Education, 25, 1049-1079. https://doi.org/10.1080/0950069032000032199

[21] Linnansaari, J., Viljaranta, J., Lavonen, J., Schneider, B. and Salmela-Aro, K. (2015) Finnish Students' Engagement in Science Lessons. Nordic Studies in Science Education, 11, 192-206. https://www.journals.uio.no/index.php/nordina/article/view/2047 https://doi.org/10.5617/nordina.2047

[22] Pascarella, E.T. and Terenzini, P.T. (1980) Student Faculty and Student-Peer Relationships as Mediators of the Structural Effects of Undergraduate Residence Arrangements. Journal of Educational Research, 73, 344-353. https://doi.org/10.1080/00220671.1980.10885264

[23] Graham, C.R., Tripp, T.R., Seawright, L. and Joeckel, G. (2007) Empowering or Compelling Reluctant Participators Using Audience Response Systems. Active Learning in Higher Education, 8, 233-258. https://doi.org/10.1177/1469787407081885

[24] Connell, J.P., Halpern-Felsher, B.L., Clifford, E., Crichlow, W. and Usinger, P. (1995) Hanging in There: Behavioral, Psychological, and Contextual Factors Affecting Whether African-American Adolescents Stay in High School. Journal of Adolescent Research, 10, 41-63. https://doi.org/10.1177/0743554895101004

[25] Connell, J.P., Spencer, M.B. and Aber, J.L. (1994) Educational Risk and Resilience in African-American Youth: Context, Self, Action, and Outcomes in School. Child Development, 65, 493-506. https://doi.org/10.2307/1131398

[26] Ekstrom, R.B., Goertz, M.E., Pollack, J.M. and Rock, D.A. (1986) Who Drops Out of High School and Why? Findings from a National Study. Teachers College Record, 87, 367-373.

[27] Skinner, E.A., Wellborn, J.G. and Connell, J.P. (1990) What Is Takes to Do Well in School and Whether I've Got It: The Role of Perceived Control in Children's En- 
gagement and School Achievement. Journal of Educational Psychology, 82, 22-32. https://doi.org/10.1037//0022-0663.82.1.22

[28] Finn, J.D., Pannozzo, G.M. and Voelkl, K.E. (1995) Disruptive and in Attentive Withdrawn Behavior and Achievement among Fourth Graders. Elementary School Journal, 95, 421-434. https://doi.org/10.1086/461853

[29] Finn, J.D. and Rock, D.A. (1997) Academic Success among Students at Risk for School Failure. Journal of Applied Psychology, 82, 221-234. https://doi.org/10.1037/0021-9010.82.2.221

[30] Appleton, J.J., Christenson, S.L., Kim, D. and Reschly, A.L. (2006) Measuring Cognitive and Psychological Engagement: Validation of the Student Engagement Instrument. Journal of School Psychology, 44, 427-445. https://doi.org/10.1016/j.jsp.2006.04.002

[31] Schaufeli, W.B., Salanova, M., González-Romá, V. and Bakker, A.B. (2002) The Measurement of Engagement and Burnout: A Two Sample Confirmatory Factor Analytic Approach. Journal of Happiness Studies, 3, 71-92. https://doi.org/10.1023/A:1015630930326

[32] Carle, A., Jaffee, D., Vaughan, N. and Eder, D. (2009) Psychometric Properties of Three New National Survey of Student Engagement Based Engagement Scales: An Item Response Theory Analysis. Research in Higher Education, 50, 775-794. https://doi.org/10.1007/s11162-009-9141-Z

[33] Krause, K.L. and Coates, H. (2008) Students' Engagement in First-Year University. Assessment \& Evaluation in Higher Education, 33, 493-505. https://doi.org/10.1080/02602930701698892

[34] Leithwood, K. and Jantzi, D. (2000) The Effects of Transformational Leadership on Organizational Conditions and Student Engagement with School. Journal of Educational Administration, 38, 112-129. http://eric.ed.gov/?id=ED432035 https://doi.org/10.1108/09578230010320064

[35] Archambault, I., Janosz, M., Fallu, J.S. and Pagani, L.S. (2009) Student Engagement and Its Relationship with Early High School Dropout. Journal of Adolescence, 32, 651-670. https://doi.org/10.1016/j.adolescence.2008.06.007

[36] Burch, G.F., Heller, N.A., Burch, J.A., Freed, R. and Steed, S.A. (2015) Student Engagement: Developing a Conceptual Framework and Survey Instrument. Journal of Education for Business, 90, 224-229. https://doi.org/10.1080/08832323.2015.1019821

[37] Robu, V. and Sandovici, A. (2014) Understanding Student Engagement with School: A Literature Review. Management Intercultural, No. 31, 477-487.

[38] Zhao, C. and Kuh, G. (2004) Adding Value: Learning Communities and Student Engagement. Research in Higher Education, 45, 115-138.

http://www.jstor.org/stable/40197341 https://doi.org/10.1023/B:RIHE.0000015692.88534.de

[39] Barker, R.G. and Gump, P.V. (1964) Big School, Small School: High School Size and Student Behavior. Stanford University Press, Stanford.

[40] Kandiko, C.B. (2008) Student Engagement in Two Countries: A Comparative Study Using National Survey of Student Engagement (NSSE) Data. Journal of Institutional Research, 14, 71-86. http://files.eric.ed.gov/fulltext/EJ1055572.pdf

[41] Walker, C.O., Greene, B.A. and Mansell, R.A. (2006) Identification with Academics, Intrinsic/Extrinsic Motivation, and Self-Efficacy as Predictors of Cognitive Engagement. Learning and Individual Differences, 16, 1-12. https://doi.org/10.1016/j.lindif.2005.06.004 
[42] Steinmayr, R. and Spinath, B. (2009) The Importance of Motivation as a Predictor of School Achievement. Learning and Individual Differences, 19, 80-90. https://doi.org/10.1016/j.lindif.2008.05.004

[43] Ryan, A.M. and Pintrich, P.R. (1997) Should I Ask for Help? The Role of Motivation and Attitudes in Adolescents' Help Seeking in Math Class. Journal of Educational Psychology, 89, 329-341. https://doi.org/10.1037//0022-0663.89.2.329

[44] Ryan, A.M. and Patrick, H. (2001) The Classroom Social Environment and Changes in Adolescents' Motivation and Engagement during Middle School. American Educational Research Journal, 38, 437-460. https://doi.org/10.3102/00028312038002437

[45] Veiga, F., Wentzel, K., Melo, M., Pereira, T., Faria, L. and Galvão, D. (2014) Students' Engagement in School and Peer Relations: A Literature Review. In: Veiga, F.H., Ed., Students' Engagement in School: International Perspectives of Psychology and Education, Instituto de Educação da Universidade de Lisboa, Lisboa, 196-211.

[46] Fullarton, S. (2002) Student Engagement with School: Individual and School Level Influences. Longitudinal Surveys of Australian Youth Research Report No. 27, Australian Council for Education Research (ACER), Camberwell.

[47] Salanova, M., Llorens, S. and Schaufeli, W.B. (2011) "Yes, I Can, I Feel Good, and I Just Do It!" On Gain Cycles and Spirals of Efficacy Beliefs, Affect, and Engagement. Applied Psychology: An International Review, 60, 255-285. https://doi.org/10.1111/j.1464-0597.2010.00435.x

[48] Dogan, U. (2015) Student Engagement, Academic Self-Efficacy, and Academic Motivation as Predictors of Academic Performance. The Anthropologist, 20, 553-561. https://doi.org/10.1080/09720073.2015.11891759

[49] Chih-Yuan Sun, J. and Rueda, R. (2011) Situational Interest, Computer Self-Efficacy and Self-Regulation: Their Impact on Student Engagement in Distance Education. British Journal of Educational Technology, 43, 191-204. https://doi.org/10.1111/j.1467-8535.2010.01157.x

[50] Patterson, E.A., Campbell, P.B., Busch-Vishniac, I. and Guillaume, D.W. (2011) The Effect of Context on Student Engagement in Engineering. European Journal of Engineering Education, 36, 211-224. https://doi.org/10.1080/03043797.2011.575218

[51] Durán, M.A., Extremera, N., Rey, L., Fernández-Berrocal, P. and Montalbán, F.M. (2006) Predicting Academic Burnout and Engagement in Educational Settings: Assessing the Incremental Validity of Perceived Emotional Intelligence beyond Perceived Stress and General Self-Efficacy. Psicothema, 18, 158-164.

[52] Schwarzer, R. and Jerusalem, M. (1995) Generalized Self-Efficacy Scale. In: Weinman, J., Wright, S. and Johnson, M.M., Eds., Measures in Health Psychology: A User's Portfolio, Causal and Control Beliefs, NFER-Nelson, Windsor, 35-37.

[53] Rotter, J.B. (1966) Generalized Expectancies for Internal versus External Control of Reinforcement. Psychological Monographs, 80, 1-28.

https://doi.org/10.1037/h0092976 